\title{
Breast Cancer pN2 TNM Finding v7
}

National Cancer Institute

\section{Source}

National Cancer Institute. Breast Cancer pN2 TNM Finding v7. NCI Thesaurus. Code C88358.

Breast cancer with metastases in 4 to 9 axillary lymph nodes, or metastases in clinically detected internal mammary lymph nodes in the absence of axillary lymph node metastases. "Clinically detected" is defined as detected by imaging studies (excluding lymphoscintigraphy) or by clinical examination and having characteristics highly suspicious for malignancy or a presumed pathologic macrometastasis based on fine needle aspiration biopsy with cytologic examination. (from AJCC 7th Ed.) 